\title{
NOTULEN
}

VAN DE

\section{BESTLUURS- EN ALGEMEENE VERGADERINGEN}

\author{
VAN HET \\ KONINKLIJK INSTITUIT
}

VOOR DE

Taal-, Land- en Volkenkunde van Nederlandsch-Indië.

$19 \overline{17-1918 .}$ 


\section{BESTUURSVERGADERING}

\section{VAN 17 NOVEMBER 1917.}

Tegenwoordig de Heeren: Van Vollenhoven (OnderVoorzitter), Bakhuizen van den Brink (Penningmeester), Hoetink (Secretaris), Jonker, Vogel, IJzerman, Martin, Rouffaer, Juynboll en Van Berckel.

De Heeren Snouck Hurgronje en Heeres zonden bericht van verhindering.

De notulen van de vorige vergadering worden gelezen en goedgekeurd.

Met ingang van 1918 worden benoemd tot leden, de Heeren: Mr. J. L. Rhemrev, S. Jaarsma, C. Bakker, C. J. W. van Arcken en H. C. Praasterink.

Aangeteekend wordt:

$1^{\circ}$ dat zijn overleden, de leden E. Tegelberg, Mr. P. J. C. van der Stok en Mr. H. L. Drucker.

$2^{\circ}$ dat voor het lidmaatschap hebben bedankt, de Heeren Th. A. Meister, H. C. Kronouer, C. Wolff en J. W. Sloot.

$3^{\circ}$ dat van verandering van adres kennis hebben gegeven de leden Mr. J. H. Meiss, K. T. van Delden Laërne en H. van Santwijk.

Onder de contribueerende instellingen wordt opgenomen de Nederlandsche Handels Hoogeschool te Rotterdam.

Voor de "Bijdragen» zijn ontvangen de volgende opstellen:

$1^{\circ}$ Prof. Dr. Ph. S. van Ronkel: Drawidische volksnamen op Sumatra.

Wordt in handen gesteld van de Heeren Jonker en Vogel.

$2^{\circ}$ L. Berkhout:

a. Enkele aanteekeningen omtrent den Sosom-Dema.

$b$. Bijdrage tot de kennis van de Majo inwijdingsfeesten bij de Marindineezen in Zuid Nieuw-Guinea.

Wordt in handen gesteld van de Heeren Juynboll en Rouffaer. 
Mede namens den Heer IJzerman, beveelt de Heer Vogel het opstel van den Heer Rouffaer: "Oudheidkundige opmerkingen» (Notulen October j.1.) voor plaatsing in de "Bijdragen , aan, daarbij bekendstellende dat de prae-adviseurs niet met sommige conclusies van den Heer Rouffaer kunnen medegaan.

Tot opneming wordt besloten.

De Heer IJzerman deelt mede dat hij voor de "Bijdragen» heeft bestemd een afschrift van een onuitgegeven dagverhaal van het beleg van ons fort te Jacatra, voorzien van zijne noten en eene inleiding, en dat hij er prijs op zal stellen dat dit stuk zal worden opgenomen in de aflevering welke binnen kort zal verschijnen, omdat daarin voorkomt de reproductie van een kaartje waarnaar ook hij zal verwijzen.

Als na lezing van het toegezegde opstel, de Heeren Rouffaer en Hoetink van oordeel zijn dat het voor plaatsing in de «Bijdragen» in aanmerking komt, zal het in de eerstdaags verschijnende aflevering worden opgenomen.

\section{De Heer Rouffaer:}

$1^{\circ}$ biedt namens het lid M. van Geuns, voor de Bibliotheek aan : Dictionario Pangasinan-Español, compuesto por el M. R. P. Fr. Lorenzo Fernandez Cosgaya, Manila 1865, en wijst op de kostbaarheid en het belang van dit geschenk.

2 brengt de wenschelijkheid ter sprake om deel VII van de -Verspreide Geschriften» op te luisteren met een portret van Prof. Kern.

Wordt bcsloten dat het portret van Prof. Kern zal worden toegevoegd aan het laatste deel der "Verspreide Geschriften *.

$3^{\circ}$ vraagt hoe in de "Verspreide Geschriften " moet worden gehandeld ten aanzien van de zangen 13 en 14 van de Nāgarakrtāgama, welke Prof. Kern noch heeft vertaald noch heeft getranscribeerd.

Wordt besloten dat alleen de transcriptie van die zangen zal worden opgenomen, op de gebruikelijke wijze.

De Penningmeester dient, in voldoening aan het bepaalde bij art. 4 van het Huishoudelijk Reglement, de begrooting voor 1918 in en geeft ter zake eenige toelichtingen. 
De Secretaris bericht dat het lid H. T. Damsté voor de «Bijdragen» heeft ingezonden een opstel "Atjèhsche kwikleer».

Dit zal in de eerstvolgende vergadering opnieuw ter tafel worden gebracht.

Voor de Bibliotheek zijn geschenken ontvangen van:

Mevr. de Wed. Campbell-Smissaert, Mevr. de Wed. Van Deventer-Maas en van de Heeren, R. M. Surija Ningrat, Jhr. Mr. W. H. Alting ron Geusau, Mr. J. W. Ramaer, M. van Geuns, A. Th. Manusama, W. O. J. Nieuwenkamp, Dr. H. Schneider, J. F. Snelleman, B. Hoetink en C. van Vollenhoven, 'aan wie, voor zooveel noodig, dank is betuigd.

Niets meer aan de orde zijnde, sluit de Onder-Voorzitter de vergadering.

BESTUURSVERGADERING

VAN 15 DeCEMBER 1917.

Met uitzondering van de Heeren Heeres en Jonker, die kennis gaven verhinderd te wezen deze vergadering bij te wonen, zijn alle bestuursleden aanwezig.

De notulen van de vorige vergadering worden gelezen en goedgekeurd.

Tot leden worden benoemd, de Heeren G. T. Pijper en A. C. H. Buitendorp.

Aanteekening zal worden gehouden van:

$a$. het overlijden van de buitenlandsche leden Sir George C. H. Birdwood en G. Doria.

$b$. het bedanken voor het lidmaatschap door de leden $\mathrm{H}$. F. Woesthoff, H. A. Hoezoo, W. Toose en G. J. H. Westenenk.

$c$. de verandering van adres van het correspondeerend lid te Paramaribo Fred. Oudschans Dentz en van het lid H. Marcella.

In behandeling worden genomen:

$1^{\circ}$ een schrijven van het Bestuur van de Vereeniging B. B. in 
Ned.-Indië, houdende toezegging van eene jaarlijksche bijdrage van f 25 ten behoeve van de Adatrechtstichting (Not. Juni j.1.). Aan het Bestuur zal dank worden betuigd.

$2^{\circ}$ een schrijven van den Redacteur-Secretaris van het Kon. Nederl. Aardrijkskundig Genootschap van 2 dezer $N^{\circ} 4938$ ten geleide van eene *Militaire memorie der Soela-eilanden (residentie Ternate en Onderhoorigheden) met daarbij behoorende bijlage en woordenlijstens, welk stuk voor het Tijdschrift van het Aardrijkskundig Genootschap te omvangrijk wordt geacht en daarom ter beschikking van het Instituut wordt gesteld.

In handen van de Heeren Van Berckel en Jonker om prae-advies.

Voor de "Bijdragen» zijn ontvangen de volgende opstellen:

a. H. T. Damsté, "Atjèhsche kwikleer".

Overeenkomstig het prae-advies van de Heeren Snouck Hurgronje en Van Vollenhoven zal dit opstel in de "Bijdragen * worden geplaatst.

$b$. Prof. Dr. Ph. S. van Ronkel: "Mededeelingen aangaande een palataliseerend Menang-kabausch dialect».

In handen gesteld van de Heeren Juynboll en Jonker.

De begrooting voor het jaar 1918 wordt vastgesteld overeenkomstig het door den Penningmeester in de vorige vergadering ingediende ontwerp.

De Heer Van Vollenhoven geeft in overweging antwoord te verzoeken aan hen van wie nog niet is vernomen of zij bereid zijn gevolg te geven aan de uitnoodiging om eene geldelijke bijdrage te geven ten behoeve van de Adatrechtstichting. Conform.

De Heer Vogel beveelt, mede namens den Heer Jonker, het opstel van den Heer van Ronkel: "Drawidische volksnamen op Sumatra voor opneming in de "Bijdragen» aan.

Zal in de "Bijdragen" worden geplaatst.

Voorts deelt de Heer Vogel mede wat hij heeft gedaan tot verkrijging van een afprent van den Minto-steen en dat hij het voornemen heeft Lady Minto daarvan op de hoogte te brengen. 
De Heer Martin vraagt hoe het staat met het werk van den Heer Schröder over het eiland Nias.

De Secretaris zegt dat de bij dat werk behoorende kaarten slechts voor een deel hier te lande zijn aangekomen en dat de uitgever bezwaar maakt om alleen tekst en platen in den handel te brengen onder toezegging dat de kaarten zullen volgen.

\section{De Heer Rouffaer:}

$1^{\circ}$ brengt, mede namens den Heer Juynboll, verslag uit over het in hunne handen gestelde opstel van het lid L. Berkhout: - Bijdrage tot de kennis van de Majo inwijdingsfeesten bij de Marindineezen in Zuid Nieuw-Guinea, , zoomede over diens opstel : "Enkele aanteekeningen omtrent den Sosom-Dema».

Wordt besloten dat deze opstellen in de "Bijdragen» zullen worden geplaatst als toestemming zal zijn verkregen om eenige wijziging te brengen in den vorm waarin de daarbij beschreven feiten zijn behandeld.

$2^{\circ}$ vraagt of deel VII van Kern's «Verspreide Geschriften » niet voor een hoogeren prijs dan voor den gewonen in den handel zal kunnen worden gebracht nu dit deel, ook door de talrijke cliché's, aan het Instituut veel geld zal kosten.

De vergadering is van oordeel dat tot prijsverhooging niet kan worden overgegaan.

De Heer Bakhuizen van den Brink vraagt vergunning om het voor Indië bestemde bronzen borstbeeld op voetstuk van wijlen den Heer van Deventer tijdelijk te mogen opstellen in het gebouw van het Instituut.

Deze vergunning wordt gaarne verleend.

De Secretaris:

$1^{\circ}$ Verzoekt goed te keuren dat hij aan Prof. Van Vollenhoven op diens aanvraag en ten behoeve van de bibliotheek der Adatrechtstichting een exemplaar heeft afgestaan van de deelen I-XIV der Adatrechtbundels en dat hij heeft gevolg gegeven aan het verzoek van Mevrouw de Weduwe Von Rosenberg om een exemplaar te ontvangen van het vanwege het Instituut uitgegeven werk van haren echtgenoot, "Reizen naar de Geelvinkbaai.»

De gevraagde goedkeuring wordt verleend. 
$2^{\circ}$ bericht dat nog geen antwoord is ingekomen van Mevrouw de Weduwe $\mathrm{H}$. Campbell-Smissaert op de vraag welke bestemming zal worden gegeven aan de door haar geschonken boekwerken welke niet in de bibliotheek van het Instituut voor plaatsing in aanmerking komen.

$3^{\circ}$ beveelt, mede namens den Heer Rouffaer, het opstel van den Heer IJzerman: "Over de belegering van het fort te Jacatra" (Not. Nov. j.l.) voor plaatsing in de "Bijdragen" aan.

Conform.

$4^{\circ}$ zegt dat het besluit van de Directie van het Bataviaasch Genootschap van Kunsten en Wetenschappen om ter gelegenheid van het driehonderdjarig bestaan van Batavia (30 Mei 1919) een plaatwerk uit te geven waardoor de grootheid van de stad Batavia tijdens de Compagnie wordt in het licht gesteld, bij hem de vraag heeft doen rijzen of het niet op den weg van het Instituut zou liggen om eveneens de stichting van Batavia te gedenken door een hulde aan den grondvester van ons koloniaal gezag, Jan Pietersz. Coen, b. v. in den vorm van eene onverkorte uitgaaf van al diens voorhanden brieven.

De Heeren Heeres, IJzerman en Hoetink zullen in de eerstkomende bestuursvergadering hierover advies uitbrengen.

Voor de Bibliotheek zijn geschenken ontvangen van de Heeren G. P. Rouffaer, Prof. Dr. J. Ph. Vogel, M. van Geuns, Prof. Mr. C. van Vollenhoven, Dr. E. B. Kielstra, J. F. Scheltema M. A., Mr. H. van de Rivière en O. L. Helfrich, aan wie, voor zooveel noodig, dank is betuigd.

Niets meer te behandelen zijnde, sluit de Voorzitter de vergadering. 


\section{BESTUURSVERGADERING}

VAN 19 JANUARI 1918.

Aanwezig de Heeren Snouck Hurgronje (Voorzitter), Bakhuizen van den Brink (Penningmeester), Hoetink (Secretaris), Jonker, IJzerman, Heeres, Rouffaer, Juynboll en van Berckel.

De Heeren Van Vollenhoven, Martin en Vogel zonden bericht verhinderd te wezen deze vergadering bij te wonen.

De notulen van de vorige vergadering worden gelezen en goedgekeurd.

Tot gewoon lid wordt benoemd de Heer Mr. J. F. Dijkstra.

Aanteekening zal worden gehouden van het bedanken voor hun lidmaatschap door de Heeren O. Lohmann, W. J. Romswinckel, Mr. A. J. C. M. Nelissen, W. Blanken, A. D. E. Abendanon, Prof. ir. C. W. Weijs en J. H. Muller zoomede van de verandering van adres van de leden Prof. Dr. Th. W. Juynboll, Mr. G. J. H. Gunning, J. Mees en H. Dijkstra.

In behandeling komen.

$1^{\circ}$ een schrijven van de Società Asiatica Italiana $\mathrm{dd}^{\circ}$ Firenze 12 Dec. $\mathrm{a}^{\circ} \mathrm{p}^{\circ}$ waarbij deelneming wordt betuigd met het overlijden van het eerelid Prof. Dr. J. H. C. Kern en de toezending van een aan dezen geleerde gewijd artikel wordt toegezegd.

De Secretaris deelt mede dat dit drukwerk nog niet is ontvangen.

$2^{\circ}$ een schrijven van de Vereeniging "Koloniaal Instituut» te Amsterdam, d.d. 10 Januari 1918, waarbij wordt voorgesteld om in samenwerking met haar, bij Z. E. den Minister van Koloniën het nut te bepleiten van eene volledige publicatie der van de zelfbesturen in Nederlandsch-Indië uitgaande, of door het gewestelijk bestuur voor hen uitgevaardigde regelingen.

De verwezenlijking van voorschreven denkbeeld zal dezerzijds gaarne worden bevorderd en de gevraagde medewerking derhalve worden verleend.

$3^{\circ}$ een schrijven van den Directeur van het "Historisches 
Museum und Archiv der Stadt Darmstadt » van 8 dezer, waarbij dank wordt gezegd voor de toezending van een exemplaar van «H. von Rosenberg, Reistochten naar de Geelvinkbaai op NieuwGuinea» en de aanbieding wordt toegezegd van eene nog niet verschenen levensbeschrijving van dezen reiziger.

$4^{\circ}$ een schrijven van het lid-donateur Dr. C. W. Janssen van 15 dezer waarbij een bedrag van f 1000 ter beschikking van de Adatrechtstichting wordt gesteld.

Aan den schenker zal dank worden gezegd.

$5^{\circ}$ een schrijven van de N. V. Martinus Nijhoff's Boekhandel en Uitgevers Maatschappij, d.d. Januari 1918, houdende kennisgeving dat zij met het oog op de hooge buitengewone onkosten die thans op het bedrijf rusten, van 1 Januari 1918 af, voorloopig alle leveranties met eene eenvormige "tijdelijke verhooging * van $5 \mathrm{pCt}$. zal belasten.

Naar aanleiding van eene opmerking van den Voorzitter, wordt besloten de aandacht van den Minister van Koloniën te vestigen op het practische nut dat voor besturende ambtenaren in het gewest Bali en Lombok is gelegen in de bestudeering van het werk "De landsverordeningen der Balische vorsten van Lombok» door F. A. Liefrinck.

Voor de "Bijdragen" is aangeboden door Dr. J. de Hullu: "Jean Chrétien Baud's Beschouwing van de maatregelen der Compagnie in zake het muntwezen.»

In handen van de Heeren Van Berckel en Heeres.

De Heer Jonker beveelt, mede namens den Heer Juynboll, het opstel van Prof. Dr. Ph. S. van Ronkel: "Mededeelingen aangaande een palataliseerend Menang-kabausch dialect» voor plaatsing in de "Bijdragen» aan.

Conform.

De Heer Heeres:

$1^{\circ}$ stelt, mede namens den Heer IJzerman, voor om het opstel van den Heer Gijsberti Hodenpijl «De zwerftocht van Sultan Pakoe Boewana II, na diens vlucht uit den kraton te Kartasoera op 30 Juni 1742 » in de "Bijdragen» op te nemen en, zoo mogelijk, de inleiding eenigszins te bekorten. 
$2^{\circ}$ doet, mede namens de Heeren IJzerman en Hoetink, in voldoening aan de hun in de vorige vergadering verleende opdracht, het voorstel om in beginsel te besluiten om het driehonderdjarig bestaan van Batavia (30 Mei 1919) te gedenken door eene zoo volledig mogelijke uitgaaf van de brieven, besluiten en andere papieren afkomstig van Batavia's stichter, G. G. Jan Pietersz Coen; ook andere archiefstukken b.v. antwoorden van Bewindhebhers, zoomede een biografie en eene bibliografie zullen hieraan moeten worden toegevoegd om een duidelijk beeld te geven van het leven en bedrijf van den grondlegger van ons koloniaal gezag in Oost-Indië.

Nadat de Heer Heeres nog heeft uiteengezet op welke wijze het aangegeven plan zal kunnen worden verwezenlijkt, wordt het voorstel van voornoemde bestuursleden eenparig goedgekeurd. Tevens worden deze uitgenoodigd om eene commissie te blijven vormen voor de uitvoering van het aangenomen voorstel, waartoe zij zich gaarne bereid verklaren.

De Heer Rouffaer:

$1^{\circ}$ biedt voor de "Bijdragen» aan zijn thans bijgewerkte "Nota over den agrarischen rechtstoestand van de inlandsche bevolking van Java en Maduras (Not. Sept. en Oct. 1915).

$\mathrm{Zal}$ overeenkomștig het vroeger daaromtrent bepaalde, aan den Heer Van Vollenhoven worden toegezonden.

$2^{\circ}$ bericht dat Mevrouw de Weduwe W. P. Groeneveldt-van Dijk hem heeft gemachtigd mede te deelen dat zij niet alleen toestemming verleent tot, maar zelfs prijs zal stellen op de publicatie van de onder de papieren van wijlen haren echtgenoot aangetroffen voortzetting van diens werk: "de Nederlanders in China», als het Bestuur van het Instituut van oordeel is dat dit vervolg voor publicatie in aanmerking komt.

Overeenkomstig het advies van den Heer Rouffaer, die het afgewerkte gedeelte van het handschrift geheel persklaar heeft bevonden, behoudens het ontbreken van de daarin aangehaalde bijlagen, in welke leemte gemakkelijk zal kunnen worden voorzien, wordt besloten de voor de pers gereed zijnde hoofdstukken uit te geven op gelijke wijze als het hoofdwerk.

$3^{\circ}$ leest voor eene nota van Dr. N. J. Krom, waarin wordt gewezen op de wenschelijkheid dat het Bestuur van het Instituut 
zal trachten op te sporen eenige handschriften welke indertijd in handen van wijlen Dr. C. Leemans zijn geweest en thans onvindbaar zijn (het verslag van Cornelius over de eerste opname van Boroboedoer, in 1814, en de verhandelingen van Wilsen en Brumund).

De heer Krom, die van bedoelde handschriften wenscht kennis te nemen ten behoeve van de hem opgedragen beschrijving van Boroboedoer, zal worden uitgenoodigd aan te geven op welke wijze het Bestuur hem in deze behulpzaam zal kunnen wezen.

Naar aanleiding van de gevoerde beraadslaging, vestigt de Heer Heeres er de aandacht op dat een drietal teekeningen van Boroboedoer en Prambanan (vermoedelijk afkomstig uit de collectie-Casius) door hem in bruikleen aan het Instituut afgestaan, thans niet meer te vinden zijn.

De Heer Rouffaer is van oordeel dat bedoelde teekeningen stellig nog aanwezig zijn.

De Heer van Berckel brengt een met redenen omkleed advies uit over de in zijne handen gestelde "Memorie over de Soelaeilanden» door den Kapitein der Infanterie P. van Hulsteijn (Not. December jl.) en geeft als zijn oordeel te kennen dat deze memorie zeer zeker verdient in de "Bijdragen" te worden opgenomen.

De beslissing wordt uitgesteld tot ook de Heer Jonker van dit stuk en in het bijzonder van de daarbij behoorende woordenlijsten zal hebben kennisgenomen.

Inmiddels zal bij de Redactie van het Tijdschrift van het Aardrijkskundig Genootschap navraag worden gedaan naar de ontbrekende schetskaart.

De Secretaris :

$1^{\circ}$ bericht dat van de Directie der Bataafsche Petroleum Maatschappij, door tusschenkomst van het Eerelid Dr. E. B. Kielstra, ook voor 1918 eene bijdrage van f 500 is ontvangen, waarvoor reeds dank is betuigd.

$2^{\circ}$ deelt mede dat Mevr. de Weduwe M. Campbell--Smissaert heeft goedgevonden dat de door haar aan het Instituut geschonken werken welke niet van koloniale strekking zijn, aan de Koninklijke Bibliotheek of eene andere openbare instelling zullen worden aangeboden. 
$3^{\circ}$ brengt verslag uit over zijn onderhoud met den Heer J. Berkhout in verband met door diens zoon aangeboden opstellen voor de "Bijdragen.» (Not. Nov. en Dec. $a^{\circ} p^{\circ}$ ).

Alsnu wordt aan den Secretaris opgedragen in die opstellen eenige wijziging te brengen ten aanzien van den vorm alleen, waardoor het beschreven mysterie minder realistisch zal worden voorgesteld.

$4^{\circ}$ vraagt of er geen aanleiding bestaat om terug te komen op eene beslissing in de vorige vergadering genomen aangaande den prijs van Deel VII van Kern's Verspreide Geschriften, nu uit de ingediende rekening blijkt dat de daarin voorkomende lijn-clichés (behalve die van de Nāgarakrtāgama) ruim f 483 kosten.

Deze vraag wordt ontkennend beantwoord.

$5^{\circ}$ legt ter tafel:

a. aflevering 3 en 4 van deel 73 der "Bijdragen».

b. F. A. Liefrinck, Landsverordeningen van inlandsche vorsten op Bali.

De bepaling van den handelsprijs van dit werk wordt aan den Secretaris overgelaten.

$6^{\circ}$ stelt voor den handelsprijs van den "Adatrechtbundel XV (Bali en Lombok), te bepalen op f 5.-.

Conform.

$7^{\circ}$ geeft in overweging aan den Heer A. G. de Bruin te vergunnen voor een door hem uit te geven werkje over de Chineezen ter Oostkust van Sumatra gebruik te maken van een kaart van het Chineesche emigratie-gebied, welke voorkomt in het door het Instituut uitgegeven werk: J. J. M. de Groot »Het kongsi-wezen van Borneo».

Conform.

Voor de Bibliotheek zijn geschenken ontvangen van de Heeren Dr. H. J. van Giffen, Dr. J. P. Kleiweg de Zwaan, Dr. E. B. Kielstra, B. J. Suermondt, A. Schulman, Dr. A. H. Pareau, F. E. baron Mulert, Prof. Mr. C. van Vollenhoven, W. van Gelder, A. M. H. J. Stokvis.

Voor zooveel noodig, is aan de gevers dank bestuigd.

Niets meer te behandelen zijnde, sluit de Voorzitter de vergadering. 


\section{BEST UURSVERGADERING \\ VAN 16 FEBRUARI 1918.}

Aanwezig de Heeren Snouck Hurgronje (Voorzitter), Van Vollenhoven (Onder-Voorzitter), Bakhuizen van den Brink (Penningmeester), Hoetink (Secretaris), Jonker, IJzerman, Rouffaer, Juynboll en Van Berckel.

De Heeren Heeres, Martin en Vogel gaven kennis verhinderd te wezen deze vergadering bij te wonen.

De notulen van de vorige vergadering worden gelezen en goedgekeurd.

Aangeteekend wordt dat voor het lidmaatschap heeft bedankt de Heer W. F. van der Hoff, dat zijn overleden de leden E. A. von Saher en A. C. C. Klijn, en dat de leden F. Twiss, G. J. van Dongen en M. Joustra kennis gaven van verandering van adres.

In behandeling komen :

$1^{\circ}$ een schrijven van het Departement van Koloniën d.d. 29 Jan. j.1. $4^{\mathrm{e}}$ afd. $\mathrm{N}^{\circ} 767^{\mathrm{a}} / 61$, waarbij dank wordt betuigd voor het aangeboden exemplaar van het door het Instituut uitgegeven boekwerk: "Landsverordeningen van Inlandsche vorsten op Bali» door F. A. Liefrinck.

$2^{\circ}$ een schrijven van den Algemeenen Rijksarchivaris van 30 Januari j.l. $\mathrm{N}^{\circ} 66 \mathrm{G}$. waarbij uit naam der familie van wijlen den Minister van Staat J. C. Baron Baud, eenige bescheiden worden aangeboden welke handelen over de oprichting van het Instituut.

Zullen in de handschriftenverzameling worden geplaatst. Aan den schenker is dank gezegd.

$3^{\circ}$ eene rekening van de firma Martinus Nijhoff ad f 52.89 voor geplaatste advertenties.

$\mathrm{Zal}$ in handen worden gesteld van den Penningmeester der Adatcommissie.

$4^{\circ}$ een schrijven van den Heer J. Berkhout alhier d.d. 20 Januari j.l., waarbij hij mededeelt niet de verantwoordelijkheid 
te kunnen aanvaarden voor de voorgestelde wijzigingen in den vorm der door zijn zoon, het lid L. Berkhout, aangeboden opstellen.

De Secretaris zal nu met den schrijver zelf in overleg treden.

$5^{\circ}$ een voorstel van de pas opgerichte "Société d'Etudes Océaniennes» te Papeete (Tahiti) om met deze instelling in ruilverkeer te treden.

De ontvangst van het toegezegde eerste nummer van het «Bulletin» zal worden afgewacht.

De Secretaris leest het door hem opgemaakte Jaarverslag, dat tot geene opmerkingen aanleiding geeft.

Op zijn voorstel wordt bepaald dat de jaarlijksche Algemeene Vergadering zal worden gehouden op Zaterdag 16 Maart a.s.

De Penningmeester biedt de rekening en verantwoording over het jaar 1917 aan; deze wordt namens het Bestuur nagezien door de Heeren Van Berckel en IJzerman terwijl de gewone leden W. van Gelder en O. L. Helfrich zullen worden uitgenoodigd haar, overeenkomstig art. 4 slot van het huishoudelijk reglement, te beoordeelen en er in de Algemeene Vergadering verslag over uit te brengen.

Voor de vervulling der door periodieke aftreding openvallende plaatsen worden de volgende drietallen opgemaakt:

I. Vacature - Van Vollenhoven :

1. F. A. Liefrinck.

2. Prof. Mr. D. van Blom.

3. Dr. E. Moresco.

II. Vacature - Heeres :

1. Prof. Dr. Ph. S. van Ronkel.

2. Dr. N. Adriani.

3. Mr. B. H. P. van der Zwaan.

III. Vacature - Juynboll :

1. Prof. J. C. van Eerde.

2. O. L. Helfrich.

3. C. J. Westenberg.

De Heer Van Vollenhoven deelt mede dat hij zijn Naschrift 
op de nota van den Heer Rouffaer (Not. Januari j.1.) binnenkort aan dezen auteur zal kunnen toezenden.

De heer Jonker, zich vereenigende met het in de vorige vergadering door den Heer Van Berckel uitgebrachte advies, beveelt de Memorie van den Heer P. van Hulstijn over de Soela-eilanden, voor plaatsing in de "Bijdragen" aan.

De Secretaris, als redacteur van de "Bijdragen», zal met de prae-adviseurs overleggen welke van de talrijke bij deze Memorie behoorende bijlagen zullen kunnen worden opgenomen.

\section{De Heer Rouffaer:}

$1^{\circ}$ brengt over het verzoek van het lid Dr. N. J. Krom om een beroep te doen op de medewerking van den HoogleeraarDirecteur van het Rijks-Museum van Oudheden te Leiden, daar, naar de overtuiging van Dr. Krom, de in de vorige vergadering genoemde handschriften stellig zullen worden gevonden als in de handschriftenverzameling van dit Museum daarnaar zorgvuldig zal worden gezocht.

Conform.

$2^{\circ}$ deelt mede tot de ontdekking te zijn gekomen dat een der handschriften van Cornelius (over Tjandi Sewoe), thans deel uitmakende van de verzameling manuscripten van het Ethnografisch Museum te Leiden, eigendom is van het Instituut.

De heer Juynboll, Directeur van dit Museum, stemt er in toe dat bedoeld handschrift aan het Instituut wordt teruggegeven.

$3^{\circ}$ vraagt machtiging om, namens het Instituut, aan het Buitenlandsch lid C. Otto Blagden de toezending te verzoeken van de handschriften uit de door hem beschreven Mackenziecollectie, welke betrekking hebben op Hindoe-oudheden op Java.

\section{Conform.}

$4^{0}$ stelt in uitzicht dat Dr. Krom een der Cornelius-handschriften, handelende over eene reis naar de Diëng, zal bewerken voor de "Bijdragen.»

$5^{\circ}$ geeft in overweging dat het Bestuur zich zal richten tot den Minister van Koloniën met het verzoek het daarheen te 
leiden dat het bij Staatsblad van Ned.-Indië $1913 n^{\circ} 407$ geregelde toezicht op de oudheden in Ned-Indië ook die van Chineeschen oorsprong zal omvatten, waardoor op de alleroudste vestigingen van Chineezen op Java misschien gegevens zullen worden verkregen welke voor de geschiedenis van belang zijn.

Conform.

$6^{\circ}$ vestigt er de aandacht op dat de catalogiseering van de Europeesche handschriften van het Instituut, welke indertijd door den Heer Versteegh is ter hand genomen, onvoltooid is gebleven.

De Heeren Van Berckel en Hoetink verklaren zich bereid deze taak ten einde te brengen.

De Heer Bakhuizen van den Brink deelt mede dat, door tusschenkomst van het Eerelid Dr. E. B. Kielstra, van den Heer A. Ed. Dinger eene bijdrage van f 250.- is ontvangen ten behoeve van het Bibliotheek-fonds.

\section{De Secretaris:}

$1^{\circ}$ legt ter tafel een exemplaar van deel VII van Kern's "Verspreide Geschriften » en van de aflevering 3-4 van deel 73 der "Bijdragen».

$2^{\circ}$ brengt, mede namens de Heeren Heeres en IJzerman, verslag uit over eene bespreking welke zij hebben gehouden met Dr. H. T. Colenbrander, over het plan om de brieven enz. van G. G. J. P. Coen uit te geven (Not. Januari j.l.) en waarbij de Heer Colenbrander zich bereid heeft verklaard zich met de uitvoering van deze taak, overeenkomstig de inzichten van het Bestuur, op zekere voorwaarden, te belasten.

Overeenkomstig het voorstel van den Heer IJzerman, wordt thans besloten om den Minister van Koloniën te verzoeken te willen bevorderen dat voor deze uitgaaf eene subsidie van f 5000. - ten laste van de Indische begrooting beschikbaar wordt gesteld.

$3^{\circ}$ biedt voor de "Bijdragen» aan, zijn opstel "Ni Hoekong".

In handen van de Heeren Van Vollenhoven en IJzerman om prae-advies. 
Voor de Bibliotheek zijn geschenken ontvangen van de Heeren: W. van Gelder, Dr. N. J. Krom, Dr. E. B. Kielstra, J. F. Snelleman, G. P. Rouffaer, Prof. Mr. Ph. Kleintjes, M. van Geuns, A. C. F. en L. L. Bierens de Haan en R. M. Noto Soeroto, aan wie, voor zooveel noodig, dank is betuigd.

Niets meer aan de orde zijnde, sluit de Voorzitter de vergadering.

\section{BESTUURSVERGADERING \\ VAN 16 MAART 1918.}

Aanwezig de Heeren Snouck Hurgronje, Jonker, Vogel, IJzerman, Rouffaer, Van Berckel, Bakhuizen van den Brink, Liefrinck, Van Ronkel en Hoetink.

Naar aanleiding van het bepaalde bij art. 10 van het Reglement, worden verkozen de Heeren Snouck Hurgronje tot Voorzitter, Liefrinck tot Onder-Voorzitter, Bakhuizen van den Brink tot Penningmeester en Hoetink tot Secretaris.

Tot lid worden benoemd, de Heeren G. van Gelder en H. J. Vermeer.

Voor het lidmaatschap heeft bedankt de Heer M. Juddel, terwijl zijn overleden de leden M. van Geuns en H. W. Fischer.

Ingekomen is:

$1^{\circ}$ eene missive van den Minister van Koloniën d.d. 22 dezer, $4^{\mathrm{e}}$ afd. $\mathrm{N}^{\circ} 26$ waarbij toezending wordt verzocht van honderd exemplaren van het werk "Landsverordeningen van Inlandsche vorsten op Bali» door F. A. Liefrinck.

De Secretaris deelt mede dat het noodige is verricht.

$2^{\circ}$ een schrijven van den Hoogleeraar-Directeur van het RijksMuseum van Oudheden te Leiden d.d. 27 Febr. j.l. $\mathrm{N}^{\circ} 7$ A., houdende mededeeling dat vruchteloos is gezocht naar de door Dr. N. J. Krom aangeduide handschriften en dat aan genoemd 
lid gaarne gelegenheid zal worden gegeven om het archief van het museum na te gaan.

De Secretaris heeft den Heer Krom van dit schrijven in kennis gesteld.

$3^{\circ}$ een rondschrijven van de Vereeniging: "Koloniaal Onderwijs Congres» waarbij wordt verzocht de contributie te willen bepalen over 1917 en 1918 volgens eene aangegeven schaal.

Wordt besloten de contributie vast te stellen op f 10 over de jaren waarin een Congres zal worden gehouden en over andere jaren op de helft van dat bedrag.

De Heer Jonker biedt namens den zendeling Johan Schut voor de "Bijdragen» aan een Boeroesch verhaal, met vertaling en aanteekeningen.

Om prae-advies gesteld in handen van de Heeren Jonker en Van Ronkel.

De Heer Vogel geeft een overzicht van hetgeen hij heeft gedaan om een afprent te krijgen van den Minto-steen (Not. Sept., Oct., Dec. $a^{\circ} p^{\circ}$ ) en leest voor een aan hem gericht schrijven van Lady Minto, waaruit blijkt dat op hare medewerking ten volle zal kunnen worden gerekend, zoodra de Engelsche geleerde wiens hulp de Heer Vogel heeft ingeroepen in staat zal zijn zich voor het aangegeven doel naar Schotland te begeven.

De Heer IJzerman:

$1^{\circ}$ biedt voor de Bibliotheek ten geschenke aan: John Griffith, Paintings of the Buddhist Cave-temples of Ajanta.

De Voorzitter zegt den Heer IJzerman dank voor dit nieuwe blijk van zijne belangstelling in de bibliotheek van het Instituut.

$2^{\circ}$ geeft, mede namens het afgetreden bestuurslid Van. Vollenhoven, in overweging het opstel "Ni. Hoekong», van den Heer Hoetink, in de "Bijdragen» op te nemen.

Conform.

De heer Rouffaer:

$1^{\circ}$ wijdt een woord van weemoedige en dankbare herinnering aan wijlen het lid M. Van Geuns, door wiens toedoen de Koloniale Bibliotheek zoo aanzienlijk is verrijkt. 
$2^{\circ}$ deelt mede een afschrift te hebben ontvangen van Prof. Van Vollenhoven's Naschrift (Not. Febr. j.1.).

\section{De Secretaris :}

$1^{\circ}$ brengt over het voorstel van het afgetreden bestuurslid Van Vollenhoven om de kosten van de door de Adatcommissie geplaatste advertenties in. 1917 , te voldoen uit de kas van het Instituut.

\section{Conform.}

$2^{\circ}$ vestigt, eveneens namens den Heer Van Vollenhoven, de aandacht op een in het nummer van heden van het weekblad «Buiten» voorkomend opstel: «De gebouwen der Oost-Indische Compagnie», met afbeeldingen, hetwelk opnieuw de vraag doet rijzen hoe het staat met de werkzaamheden der Commissie, waarvan o. a. sprake is in de notulen van October 1915, bl. XXVIII.

Aan den Secretaris wordt opgedragen navraag te doen bij Prof, Heeres.

$3^{\circ}$ legt ter tafel het eerste nummer van het «Bulletin de la Société d'Etudes Océaniennes» te Papeete (Tahiti) welke vereeniging den wensch heeft te kennen gegeven met het Instituut in ruilverkeer te treden (Not. Febr. j.1.).

Wordt besloten deze vereeniging te plaatsen op de lijst van instellingen waarmede wordt geruild.

Voor de bibliotheek zijn geschenken ontvangen van de Heeren E. C. Abendanon, Dr. E. B. Kielstra, R. M. Noto Soeroto, Prof. Mr. C. van Vollenhoven en Mr. T. C. Lekkerkerker, aan wie, voor zooveel noodig, dank is gezegd.

Niets meer te behandelen zijnde, sluit de Voorzitter de vergadering. 


\section{ALGEMEENE VERGADERING}

VAN 16 MAART 1918.

Aanwezig de Heeren Snouck Hurgronje (Voorzitter), Van Vollenhoven (Onder-Voorzitter), Bakhuizen van den Brink (Penningmeester), Hoetink (Secretaris), Jonker, Vogel, IJzerman, Rouffaer, Juynboll en Van Berckel bestuursleden; het eerelid Kielstra en de gewone leden Liefrinck, Bosboom, van Rijn van Alkemade, Helfrich, Hunger, Van Gelder, Meijer, Schmülling, van Ronkel en Bik.

De Voorzitter opent de vergadering en verzoekt den Secretaris het Jaarverslag over 1917 voor te lezen.

Nadat is gebleken dat geen der aanwezigen naar aanleiding van dit Jaarverslag eene opmerking wenscht te maken, deelt de Voorzitter mede dat de rekening en verantwoording van den Penningmeester, op verzoek van het Bestuur, is nagezien door de leden Van Gelder en Helfrich.

Mede namens den Heer Helfrich, verklaart de Heer Van Gelder dat zij'de geldelijke administratie hebben nagegaan en onderzocht, dat zij die in de beste orde hebben bevonden en dat zij daarom voorstellen den Penningmeester acquit en décharge te verleenen.

Aldus wordt besloten, waarna de Voorzitter, namens de Vergadering, den Heeren Van Gelder en Helfrich dank zegt voor de genomen moeite.

Thans is aan de orde de verkiezing van drie bestuursleden ter vervanging van de aftredende leden Van Vollenhoven, Heeres en Juynboll.

De Voorzitter noodigt de Heeren Meijer en Schmülling uit als stemopnemers te fungeeren.

De uitslag van de stemming blijkt te wezen dat met groote 
meerderheid zijn gekozen de Heeren Liefrinck, Van Ronkel en Van Eerde.

De beide eerstgenoemde verklaren de benoeming te aanvaarden; aan den Heer Van Eerde zal de uitslag der stemming worden medegeeld.

De Voorzitter zegt dank aan de heeren stemopnemers.

Aan de aanwezige aftredende bestuursleden Van Vollenhoven en Juynboll geeft de Voorzitter de verzekering dat hun arbeid voor en hunne belangstelling in het Instituut zeer op prijs zijn gesteld.

Bij de rondvraag blijkt geen der aanwezigen iets in het midden te willen brengen, waarop de Voorzitter de vergadering sluit. 


\section{JAARVERSLAG OVER 1917.}

Het Bestuur bestond in het afgeloopen jaar uit de Heeren: Prof. Dr. C. Snouck Hurgronje, Voorzitter; Prof. Mr. C. van Vollenhoven, Onder-Voorzitter; Ch. R. Bakhuizen van den Brink, Penningmeester, B. Hoetink, Secretaris; Prof. Mr. J. E. Heeres, Dr. H. H. Juynboll, Prof. Mr. Dr. J. C. G. Jonker: Prof. Dr. J. Ph. Vogel, Mr. G. J. A. van Berckel, J. W. IJzerman, G. P. Rouffaer, en Prof. Dr. K. Martin.

Het Instituut verloor zijn oudste Eerelid door het overlijden van Prof. J. H. C. Kern, die gedurende een reeks van jaren en op velerleiwijze den naam van het Instituut heeft verhoogd. Hetgeen deze groote geleerde en beminnelijke man voor het Instituut heeft gedaan, is in de "Bijdragen* herdacht en zal in dankbare herinnering voortleven.

Eveneens zijn de buitenlandsche leden Sir George C. M. Birdwood en G. Doria door den dood aan het Instituut ontvallen.

Volgens art. 8 van het Reglement zijn de Heeren Van Vollenhoven, Heeres en Juynboll aan de beurt van aftreding.

De Adjunct-Secretaris W. C. Muller bleef zich door toewijding en hulpvaardigheid onderscheiden.

Aan de Commissarissen in Oost-Indië Dr. G. A. J. Hazeu en Dr. D. A. Rinkes wordt dank gebracht voor hetgeen zij voor onze instelling hebben gedaan.

Op 1 Januari telde het Instituut:

1 Beschermvrouw (H. M. de Koningin).

27 Buitenlandsche leden.

3 Eereleden.

93 Leden-donateurs.

549 Gewone leden en contribueerende instellíngen.

3 Correspondeerende leden.

167 Instellingen waarmede het Instituut door ruiling van werken in verbinding staat. 
In den loop van 1917 zijn verschenen:

a. "Bijdragen», deel 73 ;

b. Adatrechtbundels XIII (Borneo) en XIV (Java en Madura);

c. deel VI en deel VII van Prof. H. Kern's Verspreide Geschriften;

benevens de afzonderlijke werken:

d. J. Kats, Het Tjamoro van Guam en Saipan, vergeleken met eenige verwante talen; met opmerkingen van Prof. Mr. Dr. J. C. G. Jonker;

e. F. A. Liefrinck, Landsverordeningen van Inlandsche vorsten op Bali.

Van de kaarten behoorende bij het werk over het eiland Nias, door den Heer Schröder, is nog slechts een gedeelte hier te lande aangekomen.

Voor de tot stand brenging van de "Adatrechtstichting" heeft het Instituut zijne medewerking verleend.

Aan Prof. Dr. A. J. Wensinck heeft het Instituut geldelijken steun toegezegd ten behoeve van zijne uitgave: Concordantie van Arabische Traditieverzamelingen.

Omtrent de gewone werkzaamheden van het Bestuur wordt verwezen naar de Notulen.

De bibliotheek is ook in het afgeloopen jaar door geschenken, ruilingen en aankoopen uitgebreid. In het bijzonder heeft wijlen het lid M. van Geuns zich verdienstelijk gemaakt door gelden bijeen te brengen waaruit hij de kosten van den aankoop van belangrijke en kostbare werken voor onze bibliotheek heeft kunnen bestrijden.

Vooral kwam deze hulp te stade nu de inkomsten van het Instituut zijn geslonken, de uitgaven daarentegen beduidend zijn gestegen. Het aantal leden verminderde, de drukkosten namen in bedenkelijke mate toe en alleen door eene opleving van de belangstelling in zijn arbeid, zal het Instituut in staat blijven zijne werkzaamheid voort te zetten op de wijze als tot nog toe is geschied.

Mogen allen die dezen arbeid op prijs stellen, hun waardeering in wijden kring verbreiden. 


\section{Verkorte Balans op 31 December 1917.}

1. Algemeene kas:

Kas en kassier . . . . f. 26530.44 Gebouw, van Galenstraat 14. - 36000.Meubilair . . . . . . - memorie. Effecten, volgens koers op d ${ }^{\circ}-13893.75$

\section{Bibliotheekfonds.}

Kas en kassier . . . . f $116.29 \frac{1}{2}$ Geschatte waarde der bibliotheek

Effecten, volgens koers op do - 70000.- 25677.19 f $95793.48 \frac{1}{2}$

III. Pensioen- en ondersteuningsfonds : Kas en kassier . . . . f 215.84 Effecten, volgens koers op $d^{\circ}-11838.44$ f 12054.28
Reserve voor uitgave BoroBoedoer . . . . . . f 20021.75

Geld en geldswaarden en goederen . . . . . . 56402.64

f 76424.39

Bibliotheek . . . . . . f 70000.-

Geld en geldswaarden . . $25793.48 \frac{1}{4}$

f $95793.48 \frac{1}{2}$

Geld en geldswaarden . . f 12054.28

f 12054.28

\section{Staat der aanwezige effecten.}

Voor I. Algemeene kas:

6 certificaten $2 \frac{1}{2}$ pCt. N. W. S. . . . . . . . . . f 3528.75 12

2 obl. Leening N. I. 1916, 5 pCt. à f 500 . . . . . - 1010.-

1 Deposito N. H. Maatsch. A no 741, 4 pCt.. . . . - 1000.-

f 13893.75

Voor II. Biblotheekfonds.

5 pandbrieven $4 \frac{1}{2}$ pCt. E. N. Scheepsverbandmaatschappij . f $4550 .-$

2 aandeelen N. V. Handelscompagnie Padang. . . . . 1000.-

6 pandbrieven 5 pCt.--La Plata Hypotheekbank . . . 5805.-

5 obl. $4 \frac{1}{2}$ pCt. Alg. Bank voor zakelijk onderpand. . . - 2025.-

$5,4 \frac{1}{2}$, Nat. Bank voor belaste waarde . . . . - 3012.50

$3,4 \frac{1}{2}$, Nat. Voorschotbank Amsterdam . . . . 1320.-

1 pandbrief $4 \frac{1}{2}$ pCt. Ned. Bankinstelling voor waarden belast met vruchtgebruik enz. . . . . . . . . . - 965.-

4 pandbrieven 5 pCt. Amst. Scheepsverbandbank. . . . - 4000.-

1 schuldbewijs 5 pCt. N. I. Leening 1915 . . . . . . - 505.-

$1.5 \% "$ " $" 1917$. . . . . . 499.69

$1 \quad " \quad 4 \frac{1}{2} "$ N. staatsleening 1916 . . . . . . 995.-

1 Deposito Ned. Handelmaatschappij A no B60, 4 pCt. · $\frac{1000 .-}{\text { f } 25677.19}$ 
V.oor III. Pensioen- en ondersteuningsfonds:

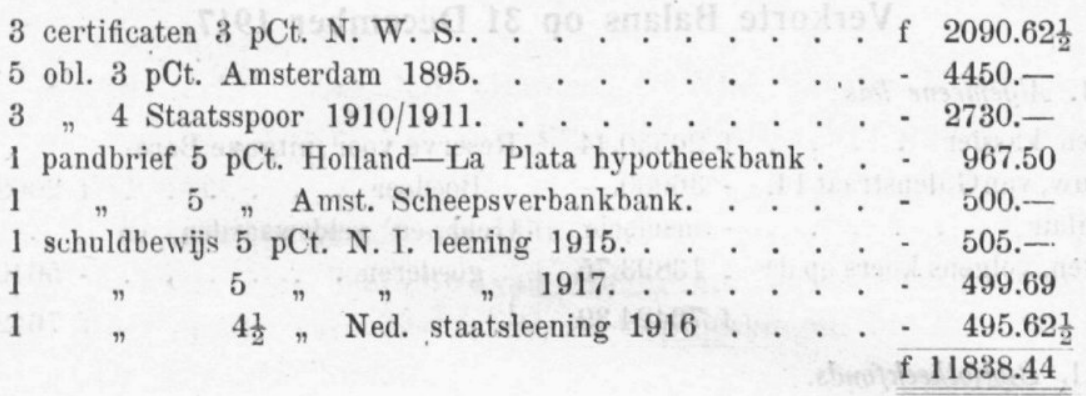

\section{Verkorte Winst- en Verliesrekening van de Algemeene Kas.}

Saldo ulto December 1916. f 6586.79

Reserve ulto Dec. 1916:

a. uitgaaf Boro-boedoer. . - 21721.75

contributiën . . . . . - 6341.65

Commissarissen in Indië. . - 550.-

Verkochte boeken. . . . - $2961.69 \frac{1}{2}$

Renten . . . . . . . . - 952.24

Aandeel Bibliotheekfonds in

algemeene onkosten . . - 2852.-

Bijdrage van Min. van Kol.

voor Schröder, Nias.

van Prof. Jonker in uitgave

Kats .

- 6250.-

- 250 . -

t $48366.22 \frac{1}{2}$
Algemeene onkosten . . . f 3899.75 Adjunct-Secretaris. . . . 1200.-

Bijdragen en afzonderlijke werken . . . . . . - 16739.Reserve:

uitgaaf Boro-boedoer . . 20021.75 vervolg Schröder, Nias . - 1000.Saldo Kas en Kassier ulto 1ec. 1917 . . . . . 5505.69

\section{Verkorte Winst- en Verliesrekening van het Bibliotheekfonds.}

Saldo ulto Dec. 1916 . . . f 82.02 Jaarlijksche donaties . . . - 3400.Schenking in eens . . . - 500.Indisch Genootschap. . . . - 466.-Renten $\cdot 1491.25$

f 5939.27
Aandeel alg. kosten . . . f 2852.Beambte. . . . . . . 600.Boeken, bindwerk, enz. . - $1774.21 \frac{1}{2}$ Brandverzekering. . . . . 72.05 Aankoop en bewaarloon effecten . . . . . . - 524.51

Saldo in kas op ulto Dec. 1917 - $116.29 \frac{1}{2}$ f 5939.37

\section{Verkorte Winst- en Verliesrekening van het pensioen- en ondersteuningsfonds.}

Saldo ulto Dec. 1916. . . . f 239.40 Aankoop en bewaarloon effecten. f 511.41 Renten.

- 487.85

f 727.25
Saldo in kas op ulto Dec. 1917. - 215.84

f 727.25 
BESTUURSVERGADERING

VAN 20 APRIL 1918.

Afwezig alleen het bestuurslid Bakhuizen van den Brink, die kennis gaf verhinderd te wezen de vergadering bij te wonen.

$\mathrm{Na}$ opening der vergadering, heet de Voorzitter het bestuurslid Prof. van Eerde welkom, waarna de Secretaris voorlezing doet van de notulen van de Algemeene Vergadering en van de Bestuursvergadering van 16 Maart j.l., welke geene aanleiding geven tot opmerkingen.

Tot nieuwe leden worden benoemd de Heeren:

R. O. van der Hout, H. U. Udo de Haas, Dr. Chr. te Lintum, H. A. van der Steenstraten en Jhr. J. C. van Reigersberg Versluijs.

Aanteekening zal worden gehouden van het overlijden van het lid-donateur M. C. Brandes en van de verandering van adres van de leden C. J. de Jaager, P. M. L. de Bruijn Prince, H. T. Damsté, C. Lekkerkerker en van de donateurs Indische Handels Compagnie en Landbouw Mij "Bangak».

In behandeling worden genomen:

$1^{\circ}$. eene missive van den Minister van Koloniën van 23 Maart j.1., $5^{\text {e }}$ afd. $n^{\circ} 39$, waarbij Z.E. mededeelt bereid te wezen te bevorderen dat voor de door het Instituut voorgenomen uitgaaf van een werk over J. P. Coen eene bijdrage van f 5000 zal worden toegekend. (Not. Febr. j.1.).

$2^{\circ}$. een schrijven van het Departement van Koloniën van' 30 Maart j.1., $4^{\mathrm{e}}$ afd. $\mathrm{N}^{\circ} 25$, waarbij toezending wordt verzocht van honderd exemplaren van het werk: ,De Landsverordeningen der Balische vorsten van Lombok», door F. A. Liefrinck.

De Secretaris deelt mede dat hieraan is gevolg gegeven. 
Voor de «Bijdragen" zijn ontvangen de volgende opstellen:

a. P. H. van de Kemp, De ontslagen Gouverneur Van Middelkoop en de Schout-bij-nacht Buijskes over den opstand in de Molukken van 1817-1818.

In handen gesteld van de Heeren Van Berckel en IJzerman.

b. Dr. J. P. Kleiweg de $Z$ waan, De verhouding tot de aangetrouwde familie in den Indischen Archipel.

In handen gesteld van de Heeren Liefrinck en Van Eerde.

c. Dr. N. Adriani: J. A. T. Schwarz als taalbeoefenaar.

In handen gesteld van de Heeren Jonker en Van Ronkel.

De Heer Jonker beveelt, mede namens den Heer Van Ronkel, het in hunne handen gestelde Boeroesch verhaal met vertaling van den Heer Schut, voor plaatsing in de «Bijdragen» aan.

Conform.

De Heer Rouffaer deelt mede dat het buitenlandsche lid Blagden hem heeft bericht reeds een afschrift klaar te hebben van een handschrift uit de "Mackenzie-collection" over een temıel op Java en dat de toezending zal plaats hebben wanneer de vereischte vergunning zal zijn verkregen. (Not. Februari j.1.).

Naar aanleiding van eene opmerking van den Heer Van Berckel, zal tot het afgetreden bestuurslid Heeres het verzoek worden gericht om onder terugzending van de Memorie-Baud (Not. Februari j.1.) zijn advies daarover te willen mededeelen.

De Secretaris doet eenige mededeelingen naar aanleiding van de in het weekblad "Buiten* opgenomen opstellen over gebouwen der O. I. Compagnie in Nederland, met het gevolg dat in bespreking komt de arbeid van de vanwege het Instituut ingestelde Commissie (Not. Juni 1907, Sept. 1914 en October 1915) voor de beschrijving van de Oost- en West-Indische gebouwen in Nederland, waaromtrent inlichtingen zullen worden ingewonnen.

Voor de Bibliotheek zijn geschenken ontvangen van de HH.: 
W. van Gelder, H. J. Jacobs, Fr. Oudschans Dentz, G. P. Rouffaer, Prof. Mr. C. van Vollenhoven, Dr. H. H. Zeylstra, T. J. Lekkerkerker, Dr. E. B. Kielstra; aan wie, voor zooveel noodig, dank is betuigd.

Niets meer te behandelen zijnde, sluit de Voorzitter de vergadering.

\section{BEST U UR S VER G A DER I N G VAN 18 MEI 1918.}

Met uitzondering van de Heeren Jonker en Van Eerde die kennis gaven verhinderd te wezen deze vergadering bij te wonen, zijn alle bestuursleden aanwezig.

De notulen van de vorige vergadering worden gelezen en goedgekeurd.

Tot gewoon lid worden benoemd, de Heeren C. L. de Bussy, R. W. Heaviside en Mr. W. Vissering.

Aanteekening wordt gehouden van het bedanken voor het lidmaatschap door de Heeren M. Reepmaker, B. Wieringa, J. G. L. Houthuysen en Mr. J. A. Levy; van het overlijden van den donateur V. C. Coster van Voorhout, zoomede van de gewone leden J. H. de Bussy, A. M. Joekes en P. Langerhuisen, en van de adresverandering van de Heeren W. Jac. Rahder en J. van der Most.

In behandeling wordt genomen:

$1^{\circ}$. eene missive van den Minister van Koloniën d.d. 29 April j.1., Afd. 5, N' 51, houdende mededeeling dat Z.E. bereid is het door het Bestuur voorgedragen denkbeeld tot uitbreiding van de taak van den Oudheidkundigen dienst met de zorg voor Oud-Chineesche monumenten (Not. Februari j.1.) aan den Gouverneur-Generaal over te brengen en voor uitvoering aan te bevelen.

Van deze beschikking wordt met waardeering kennis genomen. 
$2^{\circ}$. een schrijven van den Directeur der Kweekschool voor Inl. Onderwijzers te Fort de Kock, d.d. 3 Januari j.l., waaruit blijkt dat geene verandering is gekomen in het aantal der onder hem berustende Minangkabausche woordenboeken en grammatica's.

Kennisgeving.

$3^{\circ}$. eene circulaire waarbij een groep hier te lande aanwezige Javanen het Bestuur uitnoodigt tot bijwoning van de feestelijke viering van het tienjarig bestaan van de Vereeniging BoediOetomo.

De Onder-Voorzitter heeft zich bereid verklaard het Instituut bij die plechtigheid te vertegenwoordigen, waarvan aan belanghebbenden bericht is gegeven.

$4^{\circ}$. het schrijven van het Bestuur van den Nederlandschen Anti-Oorlog-Raad van 7 dezer, waarbij de aandacht wordt gevestigd op de gelegenheid tot het houden van vergaderingen in het tegenwoordige bureau van die Vereeniging (Princessegracht $\left.\mathrm{N}^{0} 19\right)$.

Kennisgeving.

$5^{\text {? }}$. een schrijven van de N. V. Boekhandel en Drukkerij voorheen E. J. Brill te Leiden, d.d. 16 dezer waarbij een proefexemplaar wordt aangeboden van het werk "Nias» van den Heer E. E. W. G. Schröder en tevens de feiten worden opgesomd welke er toe hebben geleid dat de kosten van uitgaaf van dit werk aanzienlijk hooger zijn geweest dan destijds is kunnen worden voorzien en begroot, zoodat de medewerking van het Bestuur wordt ingeroepen ter verkrijging van eene billijke verhonging van de ten laste der Indische geldmiddelen toegestane subsidie.

Aangezien de juistheid van de aangevoerde gronden wordt erkend, wordt na beraadslaging besloten aan het verzoek van de uitgeefster gevolg te geven als deze erkent dat alle vorderingen en aanspraken welke zij zou kunnen doen gelden in verband met de uitgaaf van het werk "Nias» op de overeengekomen wijze, volledig zullen zijn gedekt door een verhooging der subsidie met de helft van bet reeds toegestane bedrag. 
Voor de „Bijdragen» is aangeboden een opstel van Mr. A. A. de Vries: "Iets over de Indische Rechterlijke Organisatie en Rechtspraak in den tijd der Oost-Indische Compagnie».

Om prae-advies gesteld in handen van de Heeren Van Berckel en Liefrinck.

Overeenkomstig het door de Heeren Van Berkel en IJzerman uitgebrachte prae-advies, wordt besloten het opstel van het lid P. H. van der Kemp "De ontslagen Gouverneur Van Middelkoop en de Schout-bij-nacht Buijskes over den opstand in de Molukken van 1817-1818, in de "Bijdragen» op te nemen.

Ingestemd wordt met het gevoelen van de prae-adviseurs de Heeren Van Berckel en Heeres, dat de door het lid Dr. J. de Hullu beschikbaar gestelde "Beschouwing van J. C. Baud over de geldspetiën der O. I. Compagnie» (Not. Februari j.1.) voor plaatsing in de «Bijdragen» niet geschikt is.

De Heer Liefrinck beveelt, mede namens den Heer Van Eerde, het opstel van Dr. J. P. Kleiweg de Zwaan : "De verhouding tot de aangetrouwde familie in den Indischen Archipel , voor plaatsing in de "Bijdragen" aan.

Hiertoe wordt besloten. De schrijver zal worden uitgenoodigd rekening te houden met eenige door de prae-adviseurs gemaakte opmerkingen.

De Heer Rouffaer deelt mede:

$1^{\circ}$. dat hij het door het buitenlandsch lid Blagden toegezegde afschrift (Not. April j.l.) heeft ontvangen.

$2^{\circ}$. dat het lid Dr. N. J. Krom binnen kort zal kunnen indienen de hem opgedragen archaeologische beschrijving van den Boro-boedoer welke ongeveer 80 vel druks van acht bladzijden zal beslaan en geeft als zijn gevoelen te kennen dat nu de onvermijdelijke vertraging in de samenstelling van de architectonische beschrijving van dit monument ten gevolge zal hebben dat de voltooiing van deze beschrijving nog lang op zich zal laten wachten, de uitgaaf van den arbeid van Dr. Krom onverwijld ter hand genomen zal moeten worden.

De wenschelijkheid om zoo spoedig mogelijk over te gaan 
tot het drukken van Dr. Krom's archaeologische beschrijving wordt algemeen erkend, en aan den Secretaris wordt opgedragen daarover al vast in overleg te treden met den drukker van het Instituut.

$3^{\circ}$. dat de tekst van den Nagarakrtagama is gedrukt en dat ook de door Dr. Krom aan de Overdrukken (Not. September 1917) toe te voegen noten voor een goed deel gereed zijn, in verband waarmede de Heer Rouffaer ter sprake brengt welk honorarium voor laatstbedoelden arbeid zal worden toegekend.

Het voorstel van den Voorzitter om voor dezen arbeid een gelijk honorarium aan te bieden als voor in de "Bijdragen" geplaatste opstellen, wordt eenparig goedgekeurd.

De Heer Van Ronkel beveelt, mede namens den Heer Jonker, het in hunne handen gestelde opstel van het lid Dr. N. Adriani : "J. A. T. Schwarz als taalbeoefenaar», voor opneming in de «Bijdragen» aan.

Conform.

De Penningmeester bericht dat hij voor het Bibliotheekfonds een bedrag van $\mathrm{f} 1000$ in deposito heeft gegeven bij de Nederlandsche Handel $\mathrm{M}^{\mathrm{ij}}$.

Wordt goedgekeurd.

De Secretaris :

$1^{\circ}$. legt ter tafel een exemplaar van de $1^{\mathrm{e}}$ en $2^{\mathrm{e}}$ aflevering van deel 74 der "Bijdragen» en een exemplaar van Adatrechtbundel XV (Bali en Lombok).

$2^{\circ}$. bericht dat een paar dagen geleden de tweede zending van de bij het werk van het lid Schröder behoorende kaarten uit Indië is ontvangen en ter beschikking van den uitgever is gesteld.

$3^{\circ}$. biedt, namens den Heer Mr. L. H. Browne, ten geschenke aan diens volledig en keurig exemplaar van het tijdschrift: The Chinese Repository, Canton, 1833-1852. (Vgl. Cordier, Bibliotheca Sinica $2^{\text {e }}$ éd. III, p. 2286 en S. W. Williams, Recollections 
of China, in Journal N. C. Branch of the R. A. Society VIII, p. 18), en wijst op de belangrijkheid van deze aanwinst, waarmede de bibliotheek van het Instituut is verrijkt dank zij de aanbeveling van het lid $\mathrm{Mr}$. W. Vissering.

Het geschenk wordt met groote erkentelijkheid jegens de Heeren Browne en Vissering aanvaard.

$4^{\circ}$. leest voor een aan hem gericht antwoord op de aan Prof. Mr. J. E. Heeres gedane vragen naar aanleiding van de verschijning in het weekblad "Buiten» van eenige geillustreerde artikelen over gebouwen der O. I. Compagnie. (Not. April j.1.).

Wordt besloten over dit onderwerp en wat daarmede samenhangt thans het oordeel te vragen van $\mathrm{Mr}$. Dr. J. C. Overvoorde, mede-lid der Commissie ingesteld bij het besluit van het Bestuur van 15 Juni 1907.

$5^{\circ}$. biedt, namens den executeur Dr. J. H. J. van Barmen 't Loo, eenige onder de nalatenschap van het lid M. van Geuns aangetroffen handschriften en aanteekeningen aan.

Zullen in de verzameling handschriften worden opgenomen.

Voor de Bibliotheek zijn geschenken ontvangen van de Heeren Fr. Oudschans Dentz, Dr. J. de Hullu, Mr. F. D. E. van Ossenbruggen, H. F. Tillema, Dr. E. B. Kielstra, J. F. H. Ferguson, A. Plate, en Dr. H. Blink, aan wie - voor zooveel noodig - dank is betuigd.

Niets meer te behandelen zijnde, sluit de Voorzitter de vergadering. 


\section{BESTUURSVERGADERING}

VAN 16 JUNI 1918.

Tegenwoordig, de Heeren Snouck Hurgronje (Voorzitter), Liefrinck (Onder-Voorzitter), Bakhuizen van den Brink (Penningmeester), Hoetink (Secretaris), Jonker, IJzerman, Rouffaer, Martin en Van Eerde.

De Heeren Van Berckel en Van Ronkel gaven kennis de vergadering niet te kunnen bijwonen.

De notulen van de vorige vergadering worden gelezen en goedgekeurd.

Tot lid wordt benoemd (met 1 Juli a. s.) Dr. J. P. Kleiweg de Zwaan.

Aangeteekend wordt :

$1^{\circ}$ dat de N. V. Vereeniging Javasche Houthandel Maatschappijen als donateur in de plaats is gekomen van de Javasche Bosch-Exploitatie Maatschappij en de Nederlandsch-Indische Houtaankap Maatschappij.

$2^{\circ}$ dat het lid J. L. M. Swaab heeft bedankt en

$3^{\circ}$ dat de leden H. Kraemer en Mr. C. H. van Tienhoven kennis gaven van verandering van adres.

In behandeling wordt genomen :

$1^{\circ}$ een schrijven van het lid Mr. Dr. J. C. Overvoorde van 27 Mei j.l., in antwoord op eene vraag over de werkzaamheden der Commissie welke eene beschrijving en afbeeldingen zal bezorgen van gebouwen der O. I. en W. I. Compagnie in Nederland, en waarin wordt uiteengezet waaraan moet worden toegeschreven dat de arbeid van die Commissie tot nog toe onvoltooid is gebleven. 
$\mathrm{Na}$ beraadslaging wordt besloten het lid Prof. Mr. J. E. Heeres in kennis te stellen van de met den Heer Van Overvoorde gevoerde briefwisseling.

$2^{\circ}$ een schrijven van het lid Dr. N. J. Krom ten geleide van de hem door het Instituut opgedragen oudheidkundige beschrijving van den Boroboedoer.

De voltooiing van dezen. omvangrijken arbeid binnen den daarvoor noodig geachten tijd, wordt door de vergadering met ingenomenheid begroet.

De Secretaris doet mededeeling van eene bespreking met den drukker van het Instituut over Dr. Krom's handschrift, dat met inbegrip van de daarbij behoorende registers, ongeveer 80 vellen druks (groot $4^{\circ}$ ) zal beslaan.

Wordt besloten dat van de beschrijving van Dr. Krom in Nederlandschen tekst, 200 exemplaren zullen worden gedrukt op de wijze als in de vorige vergadering is vastgesteld en op de voorwaarden door den drukker van het Instituut aangegeven in zijne prijsopgaaf van 15 dezer.

De Voorzitter deelt mede dat hij van het buitenlandsche lid Prof. A. Cabaton te Parijs, het bericht heeft ontvangen dat ons buitenlandsch lid Eugène Aristide Marre den $18^{\text {en }}$ Februari 1918 in zijne villa te Vaucresson (Seine et Oise) is overleden. Vele Nederlandsche geleerden die den vriendelijken grijsaard persoonlijk gekend hebben, zijn hem in den dood voorgegaan; hij bereikte dan ook bijna den leeftijd van 95 jaren (geboren te Mamers, Sarthe 7. Maart 1823). Aristide Marre was en bleef tot in zijn hoogen leeftijd vol belangstelling in de studie der Indonesische talen.

De Heer Liefrinck brengt, mede namens den Heer Van Berckel, advies uit over het in hunne handen gestelde eerste deel van eene door Mr. A. A. de Vries aangeboden opstel over de rechterlijke organisatie en de rechtspraak onder de O. I. Compagnie.

Dienovereenkomstig wordt besloten den schrijver mede te deelen dat zijn arbeid voor plaatsing in de "Bijdragen * wel in aanmerking zal komen als rekening zal worden gehouden met eenige gemaakte opmerkingen, doch dat het Bestuur zich zijn oordeel moet voorbehouden tot van het voltooide opstel zal zijn kennis genomen. 
De Heer Jonker biedt in opdracht van het lid Dr. N. Adriani, voor de «Bijdragen» aan, een opstel van het lid Dr. Alb. C. Kruyt: "Measa II.»

In handen van de Heeren Van Eerde en Rouffaer om prae-advies.

De Heer Rouffaer verzoekt goed te vinden dat tot afsluiting van Hoofdstuk II van het oud-Javaansche letterschrift in deel VIII van Kern's Verspreide Geschriften, een lijncliché van de OudJavaansche karakters wordt toegevoegd.

Goedgekeurd.

De Secretaris deelt eenige van Dr. Colenbrander bekomen inlichtingen mede over de werkzaamheden in verband met de voorgenomen uitgaaf ter gelegenheid van de herdenking der verovering van Jacatra. (Notulen Febr. j.1.)

Voor de Bibliotheek zijn geschenken ontvangen van de Heeren S. Surija Ningrat, H. M. van Altena, Mr. W. J. M. Plate, Dr. J. M. Geerts, F. E. Baron Mulert, Wouter Nijhoff en B. Hoetink.

Niets meer aan de orde zijnde, sluit de Voorzitter de vergadering.

\section{BEST UURSVERGADERING}

\section{VAN 21 SEPTEMBER 1918.}

Alle bestuursleden zijn aanwezig, uitgezonderd de Heer Liefrinck die kennis gaf de vergadering niet te kunnen bijwonen.

De notulen van de vergadering van 16 Juni j.l. worden gelezen en goedgekeurd.

Tot leden worden benoemd, de Heeren Prof. Dr. J. Huizinga, Mr. V. W. Ch. Ploegman, A. J. Hissink, en Mr. J. A. Jonkman. Aangeteekend wordt dat de Heeren J. H. Muller, Jhr. G. van Tets, H. C. Praasterink, Jhr. Mr. A. C. D. de Graeff, J. van Aalst zoomede het St. Jozeph's Missiehuis voor het lidmaatschap hebben bedankt en dat de leden Mr. Th. B. Pleyte, D. J. C. Kriebel, Mr. J. H. L. Lebbe, Ch. Palmer van den Broek, Dr. 
H. Sundermann, A. J. Hamerster en J. G. van Heijst kennis gaven dat hun adres is veranderd.

In behandeling wordt genomen:

$1^{\circ}$ een schrijven van het Departement van Koloniën van 26 Aug. jl. $5^{\text {e }}$ Afd. $\mathrm{N}^{\circ} 5788 / 30$, houdende mededeeling dat een bedrag van $\mathrm{f} 3250$ is toegekend als verhooging van de bijdrage ten behoeve van de uitgaaf van het door den Heer E. E. W. G. Schröder samengestelde werk over het eiland Nias (Not. Mei j.l.).

De Penningmeester deelt mede dat dit bedrag aan rechthebbenden is uitbetaald.

$2^{\circ}$ een schrijven van het Hoofdbestuur van het Algemeen Nederlandsch Verbond d.d. 17 Juni j.1. waarin naar aanleiding van een brief van de Groep Antillen van dat Verbond, inlichtingen worden gevraagd omtrent den staat van voorbereiding van de oprichting van een openbare leeszaal en bibliotheek aldaar.

Aan den Secretaris wordt opgedragen over dit schrijven in overleg te treden met den Secretaris-Penningmeester van voornoemd Hoofdbestuur.

$3^{\circ}$ een schrijven van den Adjunct-Secretaris, waarbij hij zich met het oog op de tijdsomstandigheden, opnieuw voor eene verhooging van zijn salaris aanbeveelt.

Wordt besloten, gerekend van $\mathrm{p}^{0}$ Juli j.l. en zoolang de bestaande abnormale omstandigheden aanhouden, den Adjunct-Secretaris een bijslag toe te kennen van 25 pCt. van zijn salaris.

Aan den beambte der Bibliotheek wordt een dergelijke bijslag van $20 \mathrm{pCt}$. toegekend.

$4^{\circ}$ een schrijven van het oud-bestuurslid Prof. Mr. J. E. Heeres d.d. 20 dezer, waarbij Z. H. Gel., in antwoord op eene door het Bestuur gestelde vraag, mededeelt dat hij meent te mogen aannemen tegen December a.s. over genoeg tijd te kunnen beschikken om zijne gegevens over de gebouwen der O. en W. I. Compagnie uit te werken (Not. Juni j.1.).

Aan Prof. Heeres zal worden medegedeeld dat het Bestuur zich verheugt over de gedane toezegging en vertrouwt dat aan de vervulling daarvan niets meer in den weg zal komen, 
Voor de "Bijdragen" is aangeboden:

a. van het lid E. H. B. Brascamp:

«Uit het Koloniaal Archief. XXX. De Memorie en Instructie voor Jacobus Couper als Hoofd der expeditie tegen Soerapati, uitgezonden in het jaar 1684".

Om prae-advies in handen van de Heeren Van Berckel en IJzerman.

b. van het oud-bestuurslid Prof. Mr. C. van Vollenhoven: een afdruk (phototypie) van een Ceylonsch rechtsboek uit den Compagnie's-tijd, met een anoniem woord van inleiding.

Overeenkomstig het voorstel van den Voorzitter, wordt besloten tot plaatsing.

c. door tusschenkomst van den Heer Rouffaer; de volgende opstellen van het lid Dr. N. J. Krom:

$1^{\circ}$ De begraafplaats van Hayam Wuruk.

$2^{\circ}$ Epigraphische Bijdragen.

Worden om prae-advies gesteld in handen van de Heeren Rouffaer en Vogel.

d. door tusschenkomst van den Heer Van Ronkel:

"Korte mededeeling in zake het Sembiringsche doodenfeest » door het lid M. Joustra.

Overeenkomstig het advies van den Voorzitter en den Heer Van Ronkel wordt tot opneming besloten.

c. van het buitenlandsche lid C. Otto Blagden eene mededeeling: Kalpavṛkșa met een postscriptum, benevens een noot door Prof. Dr. J. Ph. Vogel daaraan toegevoegd.

Tot opneming wordt besloten.

Nog wordt in behandeling genomen een schrijven van de Commissie van Bijstand voor het oudheidkundig onderzoek in Ned. Indië d.d. 20 dezer waarbij, ingevolge een besluit in hare vergadering van $28 \mathrm{Aug}$. j.l. genomen op een voorstel van Dr.

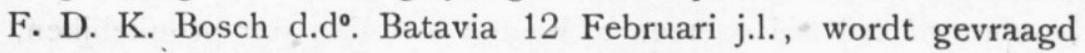
of het Instituut bereid is tot bevordering van de uitgave door den oudheidkundigen dienst in Ned. Indië van een rijkgeïllustreerd 
serie-werk bij te dragen telkens $\mathrm{f} 500$ zoodra 'een deel van dat serie-werk zal zijn verschenen, onder mededeeling dat het Bat. Gen. v. K. en W. telkens $f 1000$ voor dat doel zal beschikbaar stellen en dat zal worden getracht om zoowel van het Koloniaal Instituut als van het Ministerie van Koloniën daarvoor eene subsidie te verkrijgen.

De overweging dat de uitkomsten van den arbeid van den oudheidkundigen dienst in Ned. Indië alleszins verdienen in een zoo aantrekkelijk kleed te worden bekend gemaakt dat zij in dit opzicht niet achterstaan bij soortgelijke publicaties in andere landen, hetgeen ook zal strekken tot verhooging van den Nederlandschen naam in wetenschappelijke kringen, geeft het Bestuur aanleiding, hoewel de bekrompen geldmiddelen van het Instituut vele beperkingen opleggen, om op de vraag van de Commissie een bevestigend antwoord te geven, in het vertrouwen dat, zoo noodig, niet te vergeefs een beroep zal worden gedaan op vermogende vrienden van het Instituut wanneer hun zal kunnen worden getoond op welke wijze de toegekende subsidie is besteed.

De Heer Van Eerde, beveelt, mede namens den Heer Rouffaer, het om praeadvies in hunne handen gestelde opstel van Dr. Alb. C. Kruyt, "Measa, II, voor opneming in de "Bijdragen» aan. Conform.

\section{De Heer Rouffaer:}

$1^{\circ}$ geeft in overweging om tot den Minister van Koloniën de vraag te richten of thans nog bezwaar bestaat tegen de uitgave door het Instituut van de Nota over Midden (Nederlandsch) Timor en de Ber-Timoreezen door B. H. Franssen Herderschee (Not. Mei 1910, Juni 1910, Nov. 1911). - Conform.

$2^{\circ}$ deelt mede dat hij heeft vergeleken den tekst van Chasteleijn's Memorie zooals die is uitgegeven door het Bat. Genootschap (Tijdschrift Bat. Gen. III, 1855, bl. 63) met het handschrift dat het Instituut bezit, waarbij hem is gebleken dat beide teksten corrupt zijn doch niet op dezelfde plaatsen, zoodat het mogelijk zal wezen om uit beide een tekst te bezorgen welke mag worden beschouwd vrij wel overeen te komen met den oorspronkelijken, welke niet bekend is.

De Heer Rouffaer stelt zich voor dien arbeid ter hand te 
nemen als het Instituut bereid is om den door hem samen te stellen tekst van Chastelijn's zoo belangrijke Memorie uit te geven (Notulen October 1915).

Daartoe wordt in beginsel besloten, in de onderstelling dat de verschillen in de beide teksten belangrijk genoeg zullen blijken om eene heruitgaaf van de sInvallende Gedagten, wenschelijk te maken.

$3^{\circ}$ zet uiteen waarom hij bezwaar heeft om in deel IX der "Verspreide Geschriften» (rubriek Diversen Oud-Javaansch) in zijn geheel, zoowel tekst als noten, op te nemen het in 1875 uitgegeven werk Wṛtta-sañc'aya (tekst en vertaling); van de omvangrijke noten toch zijn drie vierden - volgens Dr. Krom verouderd.

Nadat de Heer Jonker in het midden heeft gebracht dat de door den Heer Rouffaer bedoelde grammaticale noten hebben gestrekt tot verklaring en rechtvaardiging van de vertaling door Prof. Kern gegeven, wijst de Voorzitter er op dat sedert het overlijden van dien geleerde, het Bestuur herhaaldelijk heeft beslist dat de Verspreide Geschriften moeten worden uitgegeven geheel zooals Prof. Kern die heeft te boek gesteld, zonder verandering, weglating of toevoeging, terwijl, na de opmerking van den Heer Jonker, er zeker geen reden bestaat om in dit geval van de genomen beslissing af te wijken.

De Heer Van Ronkel biedt voor de «Bijdragen» aan, zijn opstel: "Oud-Javaansche aardrijkskundige uitdrukkingen verklaard? ,

Om prae-advies gesteld in handen van de Heeren Van Eerde en Jonker.

De Penningmeester doet eene mededeeling over de geldmiddelen van het Instituut en vestigt de aandacht op een bericht in het Koloniaal Weekblad van 4 Juli. jl. $\mathrm{N}^{\circ} 27$ over een door den adjudant-onderofficier W. Matveld samengestelde memorie betreffende de landmacht in Suriname sedert 1816.

Wordt besloten den Minister van Koloniën te verzoeken een exemplaar van die memorie aan het Instituut te willen afstaan of ter lezing te geven.

De Secretaris :

$1^{\circ}$ legt ter tafel een exemplaar van het door het Instituut 
uitgegeven afzonderlijke werk van Otto Scheerer "The Particles of relation of the Isinai Languages en stelt voor den handelsprijs vast te stellen op f 3. .

Conform.

$2^{\circ}$. bericht dat het werk van den Heer Schröder over het eiland Nias thans in den handel is gebracht, tegen den prijs van $f 50$.

$3^{\circ}$ deelt mede dat van Dr. Krom's beschrijving van den Boroboedoer reeds 18 vellen zijn afgedrukt en bespreekt daarom de wenschelijkheid om naar een geschikt persoon voor de bezorging der Engelsche vertaling om te zien.

$\mathrm{Na}$ beraadslaging wordt besloten dat voor het bezorgen van die vertaling zal worden gezocht een ontwikkeld Engelschman die het Nederlandsch voldoende machtig is om den oorspronkelijken tekst te verstaan en dat Dr. Krom zal worden uitgenoodigd om, wanneer zoo'n vertaler zal zijn gevonden, dien te willen voorlichten en bijstaan.

$4^{\circ}$ geeft inzage van eene door het Encyclopaedisch Bureau uitgegeven monografie over de Soela-eilanden, met illustraties en kaart, welker tekst schijnt overeen te komen met dien der nota van den Kapitein van Hulsteijn, welke het Instituut zich heeft voorgenomen in de "Bijdragen» op te nemen.

Wordt besloten voorloopig geen uitvoering te geven aan het besluit om bedoelde nota van wege het Instituut uit te geven.

Door tusschenkomst van het lid Dr. Krom werden door het lid P. V. van Steijn Callenfels ten geschenke aangeboden een stel foto's op drie bladen, van de reliefs der Tjandi Soerawana, in de afdeeling en residentie Kediri.

Zullen, onder dankbetuiging van den schenker, worden geplaatst in de verzameling fotografiëen.

Voor de Bibliotheek zijn geschenken ontvangen:

a. van het lid Mevr. de Wed. E. M. van Deventer-Maas, door tusschenkomst van den Heer Rouffaer, een exemplaar van A. Dalrymple: A Collection of plans of ports in the East-Indies, London, 1777.

b. van de Billiton-Maatschappij, van Mevr. Hogewoning- 
Ruitenbach en van de Heeren E. Schmülling, Dr. J. P. Kleiweg de Zwaan, Dr. P. K. Acharya, Dr. E. Moresco, Mr. J. A. Jonkman, E. C. Abendanon, J. B. Wolters, J. F. Snelleman, Jhr. J. C. van Reigersberg Versluys, Dr. E. B. Kielstra, Ch. F. H. Dumont en B. Hoetink.

Aan de schenkers is, voor zooveel noodig, dank betuigd.

Niets meer aan de orde zijnde, sluit de Voorzitter de vergadering. 